\title{
PENGARUH PENGGUNAAN OKSIDAN OZON DALAM PENGEMAS PLASTIK POLIETILEN UNTUK MENYIMPAN BUAH APEL MANALAGI (malus sylvestris M)
}

\author{
Isyuniarto, Agus Purwadi \\ PTAPB - BATAN Yogyakarta
}

\begin{abstract}
ABSTRAK
PENGARUH PENGGUNAAN OKSIDAN OZON DALAM PENGEMAS PLASTIK POLIETILEN UNTUK MENYIMPAN BUAH APEL MANALAGI (malus sylvestris M). Telah dilakukan penelitian pengaruh penggunaan oksidan ozon dalam pengemas plastik polietilen untuk menyimpan buah apel manalagi (malus sylvestris M). Sebelum dilakukan penelitian, buah apel dipilih dahulu yang bentuk dan ukuran yang relatif sama, kemudian dimasukkan dalam pengemas plastik polietilen dengan tebal 3 dan $5 \mathrm{~mm}$ dan dilakukan proses ozonisasi dari 0, 20, 40 dan 60 detik. Pengamatan sampel dilakukan setiap 7, 14 dan 21 hari. Parameter yang diamati adalah tekstur buah, warna, aroma dan kesukaan panelis terhadap hasil penelitian. Dari penelitian ini diperoleh hasil yang optimal adalah dengan ketebalan plastik $3 \mathrm{~mm}$ dan waktu ozonisasi 60 detik. Pada kondisi ini buah apel masih relatif baik dan masih disukai panelis.

Kata kunci : ozon, polietilen, apel.
\end{abstract}

\section{ABSTRACT}

THE EFFECT OF OZONE OXYDAN IN PLASTIC OF POLYETHYLENE USED FOR THE STORAGE OF APPLE MANALAGI (malus sylvestris $M$ ). The effect of ozone oxydan in plastic of polyethylene used for the storage of apple Manalagi (malus sylvestris M) have been done. Firstly, apple selected according to form and size then packed into storage of plastic polyethylene 3 and $5 \mathrm{~mm}$ in thickness and ozonisation process is done from 0,20, 40 and 60 seconds. The sampel is monitored every 7, 14 and 21 days. Parametre perceived is texture of fruit, colour, smell and panelist option to this research. The result is thickly of plastic $3 \mathrm{~mm}$ and ozonisation time 60 seconds.

Keyword : ozone, polyethylene, apple.

\section{PENDAHULUAN}

B uah apel, pir, kentang atau salak, yang baru saja dikupas, daging buah atau umbinya menjadi berwarna coklat. Dalam ilmu pangan, gejala itu dinamai browning atau pencoklatan, yaitu terbentuknya warna coklat pada bahan pangan secara alami atau karena proses tertentu bukan akibat zat warna. Pada kelompok makanan tertentu, seperti pada produk bakery (berbagai roti, snack, kacang-kacangan, daging panggang, kopi, teh, dan pada permen coklat) browning umumnya diminati. Sebaliknya, pada kelompok buah-buahan seperti apel, pir, salak dan juga kentang, proses pencoklatan itu tidak dikehendaki. Pencoklatan pada buah apel dan buah lain setelah dikupas disebabkan oleh pengaruh aktivitas enzim Polyphenol Oxidase (PPO), yang dengan bantuan oksigen akan mengubah gugus monophenol menjadi O-hidroksi phenol, yang selanjutnya diubah lagi menjadi O-kuinon. Gugus O-kuinon inilah yang membentuk warna coklat. ${ }^{(1)}$

Untuk mencegah terbentuknya warna coklat pada buah itu, dilakukan blanching atau pemanasan. Caranya, buah apel setelah dikupas dan dipotong-potong direndam dalam air panas $\left(82-93^{\circ} \mathrm{C}\right)$ atau dikenai uap air panas selama 3 menit. Selanjutnya direndam dalam larutan vitamin C $200 \mathrm{mg} / \mathrm{l}$. Maksud perendaman untuk menonaktifkan enzim penyebab pencoklatan itu, sehingga menunda terbentuknya warna coklat pada buah. Dengan demikian akan didapatkan apel yang tetap segar penampilannya dan diperoleh tambahan vitamin $\mathrm{C}$ dalam buah tersebut. ${ }^{(1)}$

Buah apel adalah buah yang berdaging yang termasuk dalam golongan pome yaitu merupakan anggota famili Rosaceae dengan bagian-bagian buah yang terdiri dari kulit (epidcarp), daging buah (mesocarp), hati (core), rongga biji (endocarp) dan biji. ${ }^{(2)}$ Di Indonesia terdapat bermacam-macam varietas apel, di antaranya yang paling banyak diusahakan dan memiliki nilai ekonomis bila dipasarkan adalah Rome Beauty dan Manalagi. ${ }^{(3)}$ Jenis apel 
manalagi diduga berasal dari negeri Belanda dan mempunyai nama asli "zoete ermgoart", dengan ciri-ciri warna kulit hijau kekuningan, bentuk buah bulat dan pori-pori kulit putih. Musim panen buah apel di daerah Batu, Malang terjadi pada bulan April dan Oktober. Namun demikian, pada bulan-bulan lain ada juga petani yang memanen buah apel sehingga selama setahun buah apel selalu ada di pasaran.

Buah apel mempunyai umur simpan yang relatif pendek, kurang lebih 7 hari pada suhu kamar, karena buah apel setelah dipetik akan mengalami perubahan komposisi dan terjadi kerusakan, yang disebabkan oleh berlanjutnya kegiatan fisiologis. Kerusakan mekanis juga dapat terjadi misalnya pecah, kulit mudah sobek dan kerusakan mikrobiologis seperti pembusukan oleh mikrobia. ${ }^{(4)}$ Pengolahan yang sering dilakukan untuk buahbuahan antara lain pengeringan, perendaman dalam gula, penggaraman, fermentasi atau dengan cara pengalengan. ${ }^{(5)}$

Berdasarkan fakta tersebut, maka telah dilakukan penelitian penyimpanan buah apel dengan ozonisasi (variasi waktu ozonisasi) dalam kemasan plastik (variasi tebal plastik). Plastik pengemas yang digunakan dalam penelitian ini dipilih plastik polietilen. Karena plastik polietilen adalah salah satu jenis plastik yang memiliki sifatsifat yang cukup baik sebagai pengemas, antara lain memiliki daya tahan terhadap zat-zat kimia. Pada tekanan rendah bersifat fleksibel, ulet, merupakan film tipis yang cukup bersih, tidak berbau, tidak berasa, harga murah dan sangat kuat pada suhu rendah. ${ }^{(6)}$ Penggunaan plastik polietilen pernah diterapkan untuk mengemas buah apel, plastik ini dapat mempertahankan kandungan $\mathrm{O}_{2}$ rata-rata $3 \%$ pada suhu $32^{\circ} \mathrm{F}$, hal ini sangat menguntungkan buah apel yang memerlukan sedikit $\mathrm{O}_{2}$ untuk penghambatan respirasi dan etilen. ${ }^{(7)}$

Untuk ikut berperan aktif memecahkan problem pengelolaan buah apel, sesuai dengan kemampuan iptek yang dimiliki dalam pembuatan generator ozon dan aplikasinya ${ }^{(8)}$ maka BATAN Yogyakarta berpartisipasi menyumbangkan kemampuan dalam teknologi pengawetan buah paska panen. Hasil litbang dapat disosialisasikan kepada masyarakat luas pada umumnya dan pada petani buah pada khususnya.

\section{TATA KERJA}

\section{BAHAN}

Buah apel manalagi berukuran $\mathrm{A} 3$, bentuk bulat dan warna hijau kekuningan yang diperoleh dari Pasar Gamping, Sleman, Yogyakarta, bahan kimia untuk analisis terdiri atas : aquades, indikator PP $1 \%$ (p.a), $\mathrm{NaOH}$ $0,1 \mathrm{~N}$ (р.a), Pb asetat (р.a), $\mathrm{Na}_{2} \mathrm{CO}_{3}$ anhidrat (p.a), reagensia Nelson (p.a), reagensia arsenolmolybdat (р.a), Plastik polietilen dengan tebal 3 dan $5 \mathrm{~mm}$.

\section{ALAT}

Alat preparasi bahan, antara lain : ozonizer, selang, timbangan, plastik dan pompa udara, peralatan analisis tekstur dan uji pembedaan, antara lain : penetrometer, timbangan analitik, pipet gondok, erlenmeyer, tabung reaksi, gelas ukur, kertas saring, pipet tetes, buret, corong gelas, pengaduk kaca, pengaduk sintetik, sendok stainless, spektrofotometer, kompor listrik, labu takar, vortex, cawan dan nampan.

\section{CARA KERJA}

1. Buah apel segar disortasi terlebih dahulu, kemudian dimasukkan ke dalam plastik polietilen dengan ketebalan 3 dan $5 \mathrm{~mm}$ dan direkatkan. Setiap kantung plastik diisi 6 buah apel. Kemudian kantong plastik yang berisi buah apel tersebut diozonisasi selama 0 detik, 20 detik, 40 detik dan 60 detik. Lama penyimpanan selama 21 hari dengan 3 kali pengamatan. Pengamatan dilakukan setiap 7 hari, 14 hari dan 21 hari. Setiap pengamatan dilakukan analisis tekstur dari buah apel, kemudian pada akhir penyimpanan dilakukan uji kesukaan panelis terhadap buah apel hasil penelitian, yang berupa uji warna, aroma dan uji kesukaan.

2. Analisis buah sebelum dan sesudah diozonisasi adalah analisis tekstur dan uji pembedaan yang berupa uji warna, uji aroma dan uji kesukaan.

3. Pengamatan buah apel yang tidak diozonisasi (kontrol). 


\section{HASIL DAN PEMBAHASAN}

Kekerasan buah apel secara kuantitatif diukur dengan penetrometer. Hasil pengukuran kekerasan buah apel selama penyimpanan dapat dilihat pada Gambar 1.

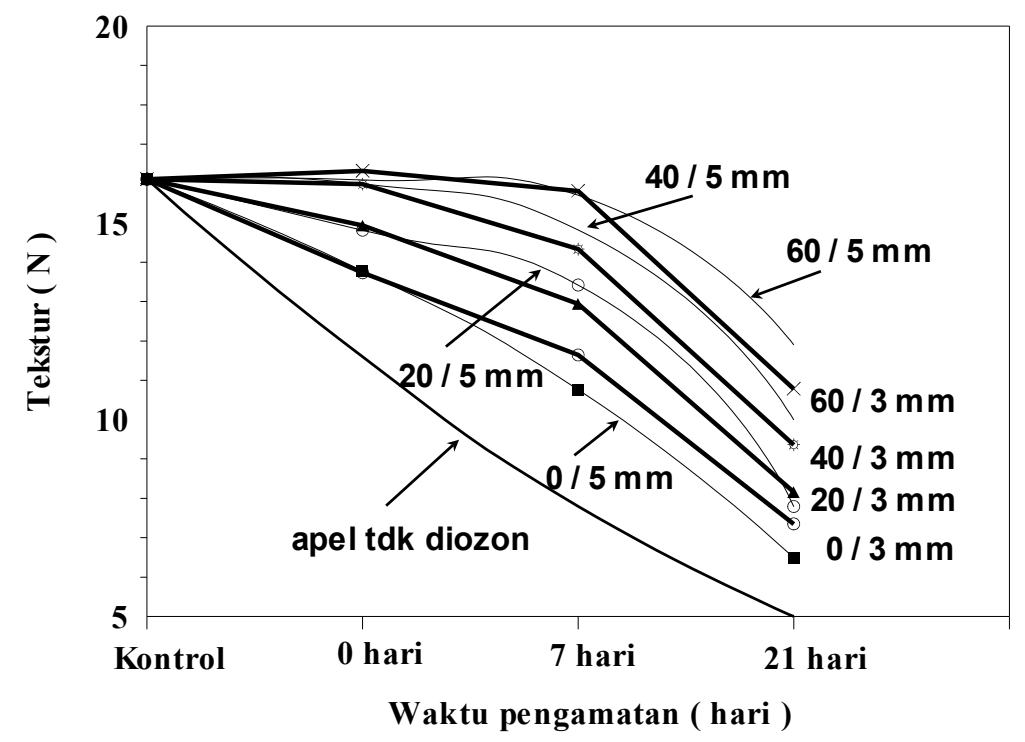

Gambar 1. Pengaruh waktu ozonisasi dan tebal plastik terhadap tekstur buah.

Pada Gambar 1 terlihat bahwa komposisi ozon dalam plastik ternyata sangat berpengaruh nyata terhadap kekerasan buah apel. Selama penyimpanan kekerasan buah apel semakin turun. Kecuali perlakuan 60 detik / 3 $\mathrm{mm}$ dan 60 detik $/ 5 \mathrm{~mm}$, pada perlakuan ini kekerasan relatif agak dihambat. Hal ini dikarenakan adanya laju respirasi yang diperlambat, sehingga kekerasan dapat bertahan sampai hari ke 21. Penurunan kekerasan buah apel selama penyimpanan disebabkan oleh pembongkaran protopektin menjadi asam pektat dan pektin yang bersifat mudah larut, pembongkaran tersebut terjadi melalui depolarisasi atau pemendekan rantai dan diesterifikasi atau penghilangan gugus metil dari polimernya. ${ }^{(9)}$

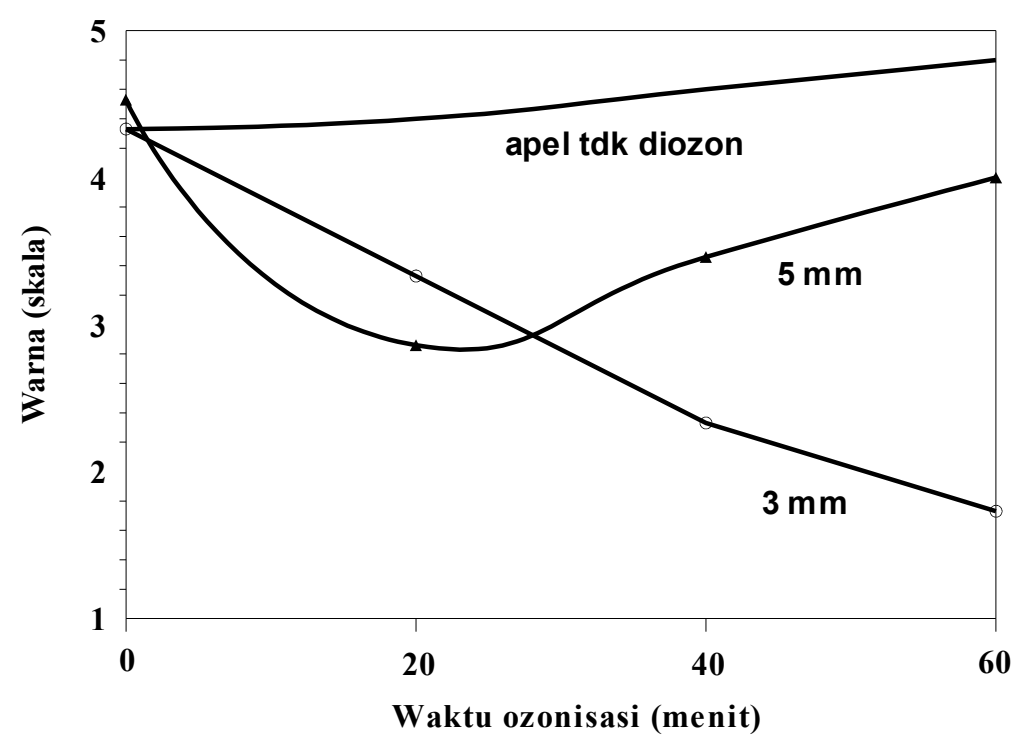

Gambar 2. Pengaruh waktu ozonisasi dan tebal plastik terhadap warna buah. 
(catatan : angka semakin besar menunjukkan warna buah semakin tidak disukai).

Penerimaan konsumen ditentukan oleh kualitas buah. Tingkat penerimaan konsumen dapat diprediksi dengan uji pembedaan menggunakan sejumlah panelis sebagai wakil konsumen. Tingkat kesukaan panelis terhadap buah apel selama penyimpanan ditentukan dengan penilaian panelis terhadap berbagai atribut mutu buah. Atribut mutu yang digunakan meliputi warna, aroma dan keseluruhan. Warna adalah sebutan untuk semua sensasi yang timbul dari aktivitas retina mata manusia dan hubungannya dengan mekanisme urat syaraf pada saat sinar mencapai retina. ${ }^{(10)}$ Tingkat panelis terhadap warna buah apel disajikan pada Gambar 2.

Perubahan warna merupakan perubahan yang paling menonjol pada waktu pemasakan. Pada tahap pematangan terakhir terjadi sintesis karotenoid. Senyawa-senyawa yang dilepaskan pada pemecahan klorofil digunakan untuk sintesis karotenoid. Perubahan warna dari hijau ke kuning ditandai dengan hilangnya klorofil dan muncul zat warna karotenoid. Selama masih berwarna hijau dalam flavedo yang mengandung klorofil masih terjadi sedikit kegiatan fotosintesis. ${ }^{(9)}$ Pada penelitian ini tingkat kesukaan panelis terhadap warna buah apel dipengaruhi oleh kondisi penyimpanan. Pada Gambar 2 ditunjukkan bahwa warna buah apel yang disukai adalah pada perlakuan 60 detik $/ 3 \mathrm{~mm}$, hal ini dikarenakan pada perlakuan tersebut respirasi dapat dihambat sehingga warna buah masih terlihat baik dibandingkan perlakuan yang lain.

Aroma khas yang timbul pada buah masak biasanya berasal dari senyawa ester alkohol alifatik dan asamasam lemak berantai pendek. ${ }^{(9)}$ Derajat kemasakan merupakan faktor fisiologis utama yang mempengaruhi produksi zat-zat atsiri, tetapi komposisi aroma buah sangat dipengaruhi oleh keadaan lingkungan selama pemasakan. ${ }^{(9)}$ Tingkat kesukaan panelis terhadap aroma buah apel selama penyimpanan dalam plastik dapat dilihat pada Gambar 3.

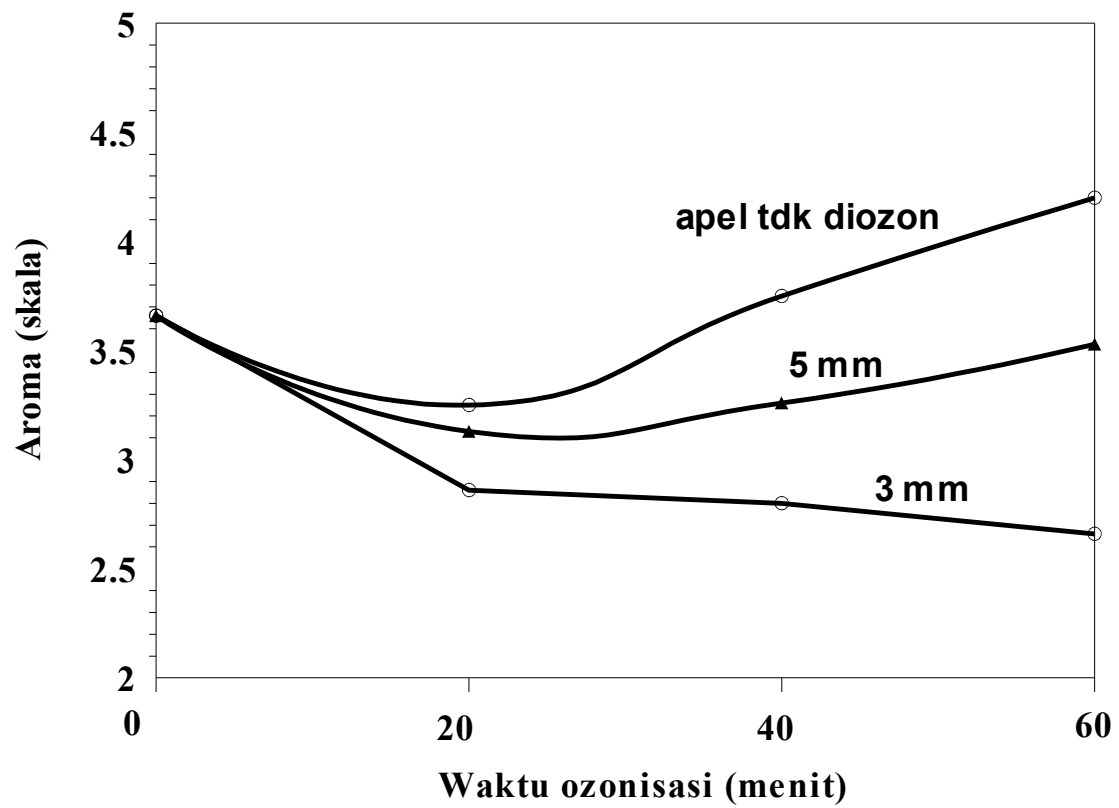

Gambar 3. Pengaruh waktu ozonisasi dan tebal plastik terhadap aroma buah. (catatan : angka semakin besar menunjukkan aroma buah semakin tidak disukai).

Tingkat kesukaan panelis terhadap aroma buah apel dipengaruhi oleh kondisi penyimpanan. Pada penelitian ini, aroma yang paling disukai adalah pada perlakuan 60 detik $/ 3 \mathrm{~mm}$, hal ini disebabkan laju respirasinya lebih kecil dibandingkan dengan perlakuan lain sehingga sangat mungkin buah dalam perlakuan tersebut masih dapat menghasilkan atsiri (senyawa aromatik). Senyawa atsiri apapun yang dikeluarkan oleh buah hanya jelas teramati pada permulaan kematangan saja. ${ }^{\left({ }^{9}\right)}$ 
Parameter kesukaan digunakan untuk mengetahui tingkat kesukaan konsumen terhadap buah setelah menilai berbagai macam parameter secara mandiri. Kesukaan panelis terhadap keseluruhan mutu buah apel dapat dilihat pada Gambar 4.

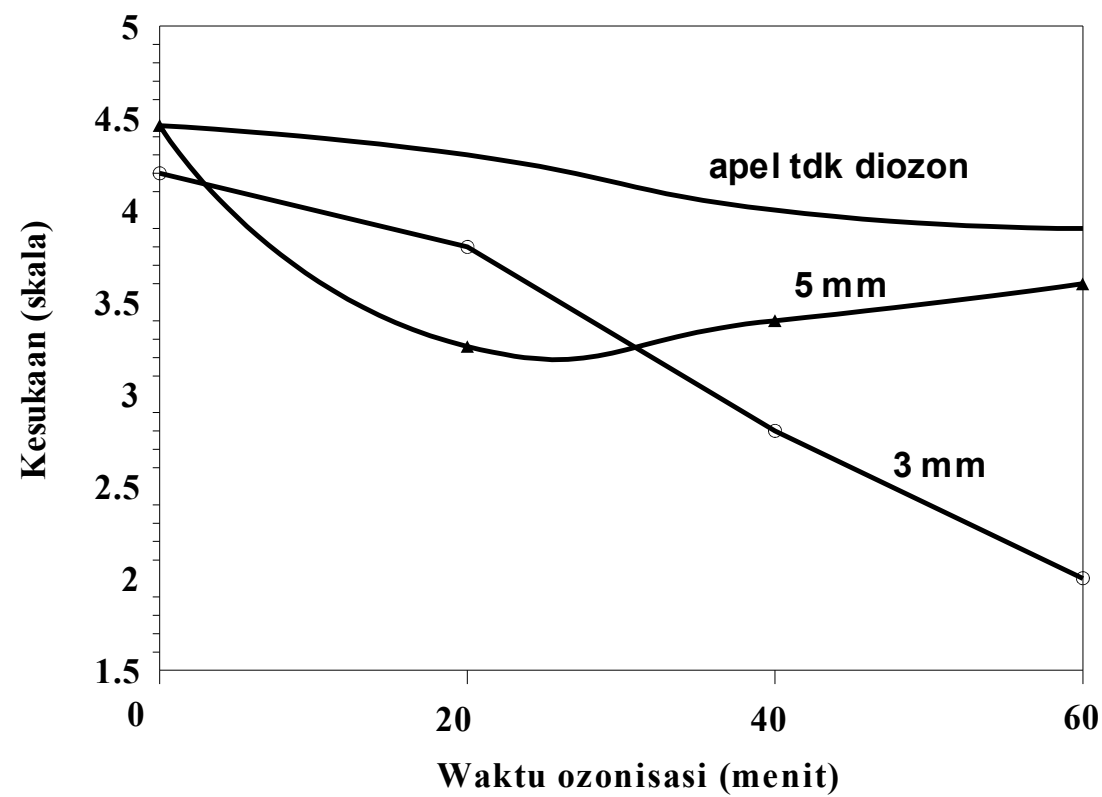

Gambar 4. Pengaruh waktu ozonisasi dan tebal plastik terhadap kesukaan buah. (catatan : angka semakin besar menunjukkan bahwa buah semakin tidak disukai).

Tingkat kesukaan panelis terhadap buah apel dipengaruhi oleh kondisi penyimpanan. Buah segar yang paling disukai panelis adalah perlakuan 60 detik $/ 3 \mathrm{~mm}$. Hal ini disebabkan laju respirasi yang rendah sehingga penampakan lebih baik dibandingkan perlakuan yang lain.

\section{KESIMPULAN}

Dari penelitian yang telah dilakukan, maka dapat diambil suatu kesimpulan, bahwa :

a. Ketebalan plastik dan lama ozonisasi dapat mempengaruhi umur simpan buah apel selama penyimpanan.

b. Perlakuan terbaik untuk penyimpanan buah apel dalam penelitian ini adalah plastik polietilen dengan ketebalan $3 \mathrm{~mm}$ dan lama ozonisasi 60 detik.

\section{UCAPAN TERIMA KASIH}

Dengan selesainya penelitian ini disampaikan ucapan terima kasih yang sebesar-besarnya kepada Sdri. Fitria Istiqomah, mahasiswi tugas akhir Fak. Pertanian Universitas Wangsa Manggala Yogyakarta dan rekan-rekan teknisi Kelompok Plasma, atas bantuannya dari awal hingga selesainya penelitian ini.

\section{DAFTAR PUSTAKA}

1. http://warintek.progressio.or.id/tips.htm, diakses tanggal 4 September 2006.

2. SYLVANIA, F., "Penyimpanan Buah Apel Manalagi (malus sylvestris Mill) dengan Udara Terkendali dalam Kemasan Plastik", Skripsi FTP UGM, Yogyakarta, (1999).

3. KUSUMO, S., Budidaya Apel, Lembaga Penelitian Holtikultura, Jakarta, (1986).

4. WINARNO, F.G., Pangan Gizi Teknologi dan Konsumen, PT Gramedia. Jakarta, (1992).

5. DJARIR, M., Deskripsi Pengolahan Hasil Nabati, Agritech, Yogyakarta, (1982).

6. SUYITNO, Pengemasan Produk Olahan, Kursus singkat Kemasan Bahan Makanan dengan Plastik, PAU Pangan dan Gizi, UGM, Yogyakarta, (1993). 
7. TRANGGONO DAN SUTARDI, Biokimia dan Teknologi Pasca Panen, PAU Pangan dan Gizi, UGM, Yogyakarta, (1990).

8. AGUS PURWADI dkk., "Studi dan Pembuatan Generator Ozon Menggunakan Lucutan Listrik" , Jurnal Nusantara Kimia, Vol. VIII, No. 1, Januari (2001).

9. PANTASTICO, Fisiologi Pasca Panen. Penanganan dan Pemanfaatan Buah-buahan dan Sayur-sayuran Tropika dan Subtropika, Terjemahan Kamarijani. Editor Gembong Tjitrosoepomo, UGM Press, Yogyakarta, (1986).

10. WINARNO, F. G., AMAN, M., Fisiologi Lepas Panen, Sastra Budaya, Jakarta, (1982). 